\title{
PENERAPAN METODE MMP DAN NHT TERHADAP HASIL BELAJAR MATEMATIKA PADA MATERI TRIGONOMETRI
}

\author{
Erni Budiyanti ${ }^{1}$, Arie Purwa Kusuma ${ }^{2}$, Desy Bangkit Arihati $^{3}$ \\ ${ }^{1,2,3}$ Pendidikan Matematika, STKIP Kusuma Negara \\ arie_pk@stkipkusumanegara.ac.id
}

\begin{abstract}
Abstrak
Penelitian ini diharapkan dapat membuktikan perbedaan hasil belajar matematika siswa yang diajar dengan menggunakan metode Missouri Mathematics Problem (MMP) dan Numbered Head Together (NHT) pada materi trigonometri. Penelitian ini dilaksanakan pada bulan Maret sampai April 2018, dengan metode eksperimen. Sampel dari penelitian ini berjumlah 72 siswa, 36 siswa di kelas X Elektro 2 yang menggunakan metode Missouri Mathematics Project (MMP) dan 36 siswa di kelas X Elektro 1 yang menggunakan metode Numbered Head Together (NHT), pemilihan sampel penelitian secara cluster random sampling. Instrumen yang digunakan dalam penelitian ini adalah soal tes materi trigonometri berbentuk soal pilihan ganda, dari hasil ujicoba tes yang valid 25 soal dengan menggunakan reliabilitas Kuder Richardson (KR-20) diperoleh 0,9147. Berdasarkan perhitungan diperoleh data bahwa rata-rata hasil belajar siswa melalui metode Missouri Mathematics Project (MMP) memiliki rata-rata 76,5 dan rata-rata hasil belajar siswa melalui metode Numbered Head Together (NHT) memiliki rata-rata 71,33. Dalam uji prasyarat kedua data berdistribusi normal dan homogen. Pengujian hipotesis data diperoleh $t_{\text {hitung }}=2,068>t_{\text {tabel }}=1,994$. Maka diperoleh kesimpulan $\mathrm{H}_{1}$ diterima dan $\mathrm{H}_{0}$ ditolak. Dengan demikian kesimpulan penelitian ini adalah terdapat perbedaan hasil belajar matematika siswa yang menggunakan metode Missouri Mathematics Project (MMP) dan metode Numbered Head Together (NHT) pada materi Trigonometri di kelas X.
\end{abstract}

Kata Kunci: Metode MMP, Metode NHT, Hasil Belajar.
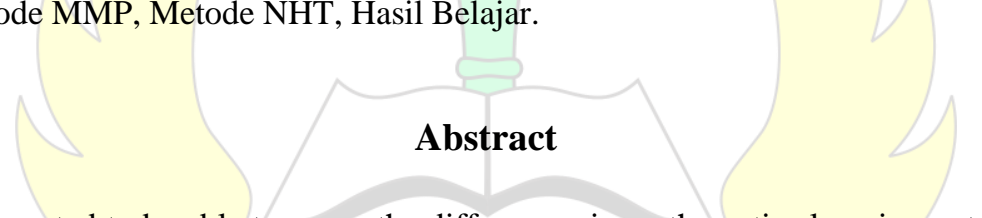

This research is expected to be able to prove the differences in mathematics learning outcomes of students taught using the Missouri Mathematics Problem (MMP) and Numbered Head Together (NHT) methods on trigonometric material. This research was conducted from March to April 2018, with an experimental method. Samples from this study amounted to 72 students, 36 students in Electrical X 2 class using the Missouri Mathematics Project (MMP) method and 36 students in Electrical X class 1 who used the Numbered Head Together (NHT) method, selecting research samples by cluster random sampling. The instruments used in this study were trigonometric material test questions in the form of multiple choice questions, from the results of a valid test test 25 questions using the reliability of Kuder Richardson (KR-20) were obtained 0.9147. Based on the calculations obtained data that the average student learning outcomes through the Missouri Mathematics Project (MMP) method has an average of 76.5 and the average student learning outcomes through the Numbered Head Together (NHT) method has an average of 71.33. In the second prerequisite test the data is normally distributed and homogeneous. Hypothesis testing data obtained by $t_{\text {obs }}=2.068>t_{\text {table }}=1.994$. Then the conclusion is $\mathrm{H} 1$ is accepted and $\mathrm{H} 0$ is rejected. Thus the conclusion of this study is that there are differences in student mathematics learning outcomes using the Missouri Mathematics Project (MMP) method and Numbered Head Together (NHT) method on Trigonometry material in class $\mathrm{X}$.

Keywords: MMP Method, NHT Method, Learning Outcomes. 


\section{PENDAHULUAN}

Pembangunan di bidang pendidikan merupakan sarana dan wahana yang sangat penting dan menentukan dalam pembinaan sumber daya manusia.Oleh karena itu bidang pendidikan perlu mendapat perhatian, penanganan dan prioritas secara sungguh-sungguh baik oleh pemerintah, masyarakat pada umumnya, dan para pengelola pendidikan pada khususnya.Sejalan dengan berkembangnya masyarakat dewasa ini pendidikan banyak menghadapi berbagai rintangan.Salah satu tantangan yang cukup menarik adalah yang berkenaan dengan peningkatan mutu pendidikan, yang disebabkan masih rendahnya mutu pendidikan di Indonesia.

Hasil studi PISA (Program for International Student Assessment) tahun 2015 yang menunjukkan Indonesia baru bisa menduduki peringkat 62 dari 72 negara. Survey ini dilakukan oleh OECD (Organisation Economic Cooperation and Development).Analisis yang digunakan oleh OECDberdasarkan pada hasil tes matematika dan ilmu pengetahuan.

Tujuan pendidikan nasional dalam GBHN adalah untuk meningkatkan kualitas manusia Indonesia, yaitu manusia yang beriman dan bertaqwa kepada Tuhan Yang Maha Esa, berbudi pekerti luhur, berkepribadian, mandiri, maju, tangguh, cerdas, kreatif, disiplin, beretos kerja, profesional, bertanggung jawab dan produktif serta sehat jasmani dan rohani. Kegiatan Belajar Mengajar (KBM) merupakan aktivitas paling penting dalam keseluruhan upaya pendidikan yang terjadi di sekolah. Hal ini/dikarenakan dengan melalui kegiatan belajar mengajar tujuan pendidikan akan tercapai, yaitu dalam bentuk perubahan perilaku pada siswa. Seseorang dikatakan telah belajar apabila terjadi perubahan tingkah laku pada orang tersebut, misalnya dari tidak tahu menjadi tahu dan dari tidak mengerti menjadi mengerti.

Salah satu disiplin ilmu yang dipelajari di sekolah adalah mata pelajaran matematika.Matematika merupakan ilmu yang mendasari perkembangan teknologi modern, mempunyai peranan penting dalam berbagai disiplin ilmu dan memajukan daya pikir manusia. Untuk menguasai dan menciptakan teknologi di masa depan diperlukan penguasaan matematika sejak dini. Oleh karena itu, mata pelajaran matematika merupakan mata pelajaran yang diberikan pada setiap jenjang pendidikan dari mulai pendidikan dasar.

Matematika adalah ilmu dasar yang berkembang sangat pesat baik materi maupun kegunaannya.Mata pelajaran ini berfungsi untuk mengembangkan kemampuan berkomunikasi dengan menggunakan bilangan dan menggunakan ketajaman penalaran untuk dapat menyelesaikan persoalan sehari-hari. Dengan kata lain belajar matematika adalah mempelajari objek kajian yang abstrak dengan pola pendekatan deduktif dan kebenaran absolut. Namun kenyataannya pembelajaran matematika di sekolah seringkali membuat siswa merasa kesulitan dan bahkan banyak siswa tidak menyukai pelajaran matematika.

Kenyataannya, matematika sering dianggap sebagai mata pelajaran yang susah untuk dimengerti. Indikasinya dapat dilihat dari hasil belajar siswa yang kurang memuaskan.Selama ini umumnya siswa hanya bermodal menghafal rumus untuk menyelesaikan soal-soal matematika.Hal tersebut dikarenakan matematika bersifat abstrak dan membutuhkan pemahaman konsep-konsep. Faktor lain yang berpengaruh adalah cara mengajar guru yang tidak tepat. Pembelajaran yang biasa diterapkan selama ini menggunakan metode ekspositori, di mana pembelajaran berpusat pada guru, siswa pasif, dan kurang terlibat dalam pembelajaran.

Tugas utama para guru matematika adalah membimbing para siswa tentang bagaimana belajar yang sesungguhnya, bagaimana belajar untuk mendapatkan informasi, ide-ide, keterampilan-keterampilan, nilai-nilai untuk memecahkan masalah yang mereka hadapi dalam kehidupan sehari- hari.Selain itu juga mengarahkan siswa untuk belajar bernalar secara logis, berpikir kritis dan mengemukakan pendapat secara sistematis.

Berdasarkan hasil wawancara dengan guru matematika SMK Negeri 1 Gunung Putri Ibu Nia Kurniawati, S.Pd pada hari Senin, 16 Oktober 2017 yaitu siswa cenderung lebih banyak diam, mendengar, dan menerima apa yang telah disampaikan oleh guru dan dalam proses pembelajaran belum menerapkanmetode pembelajaran yang bervariasi sehingga siswa kurang aktif dalam mengikuti proses pembelajaran. Wawancara juga dilakukan dengan siswa, salah satunya adalah Devita Anggraeni, ia mengatakan bahwa pembelajaran matematika itu sulit, dan saat pembelajaran matematika berlangsung terkadang mengerti dan terkadang tidak terlalu mengerti.

Penulis juga mendapatkan hasil prasurvei dari guru mata pelajaran matematika kelas X SMK Negeri 1 Gunung Putri, dapat diketahui bahwa nilai ulangan harian siswa kelas $\mathrm{X}$ tahun sebelumnya pada materi trigonometri menunjukkan bahwa dari 174 siswa yang mendapatkan nilai lebih dari 73 berjumlah 52 siswa dengan persentase $30 \%$ dan yang mendapatkan nilai kurang dari 73 berjumlah 122 siswa atau sebanyak $70 \%$ siswa kelas X SMKN 1 Gunung Putri. Hal ini menunjukkan bahwa proses pembelajaran belum menunjukkan hasil yang memuaskan karena lebih dari sebagian siswa masih mendapatkan nilai di bawah Kriteria Ketuntasan Minimal (KKM) yaitu 73. 
Nilai ulangan harian siswa yang belum memuaskan dapat disebabkan karena beberapa faktor, salah satunya adalah faktor metode pembelajarannya.Metode pembelajaran yang digunakan guru masih menggunakan metode konvensional, apalagi kesadaran siswa tentang kemandirian belajar masih sangat kurang. Akibatnya siswa cenderung pasif dalam proses pembelajaran dan kurang kreatif dalam menyelesaikan soal-soal yang diberikan oleh guru.

Suatu proses pembelajaran terdapat berbagai komponen pembelajaran yang harus dikembangkan dalam upaya mendukung tercapainya tujuan pembelajaran dan keberhasilan siswa dalam belajar. Komponen-komponen tersebut diantaranya guru, siswa, metode pembelajaran, metode pembelajaran, serta sumber dan media pembelajaran. Sebagai salah satu komponen pembelajaran, pemilihan metode pembelajaran akan sangat menunjang pencapaian tujuan pembelajaran.

Terdapat banyak metode pembelajaran, salah satunya adalah metode pembelajaran kooperatif (cooperative learning). Metode pembelajaran kooperatif merupakan bentuk pembelajaran dengan cara siswa belajar dan bekerja dalam kelompok-kelompok kecil secara kolaboratif yang anggota terdiri dari empat sampai enam orang dengan struktur kelompok yang bersifat heterogen. Pada pembelajaran kooperatif keberhasilan siswa bergantung pada keberhasilan setiap anggota kelompoknya. Untuk itu akan membuat siswa bersemangat untuk saling membantu memberikan pemahaman kepada anggota kelompoknya, sehingga bisa di pastikan bahwa semua anggota kelompoknya menguasai materi yang sedang dipelajari.

Terdapat banyak tipe metode pembelajaran kooperatif, diantaranya metode pembelajaran Missouri Mathematics Project (MMP) dan Numbered Head Together (NHT). Dalam metode pembelajaran ini siswa dituntut untuk aktif selama proses pembelajaran berlangsung. Menerapkan metode Missouri Mathematics Project (MMP) menekankan siswa terlibat aktif dalam memahami materi pada proses pembelajaran berlangsung serta menekankan kemandirian belajar siswa yang diwujudkan dengan harapan dapat membiasakan siswa untuk memecahkan masalah dan siswa dapat terampil mengerjakan soal karena banyak nya latihan yang diberikan. Penelitian Good dan Grouws (1979), Good, Grouws dan Ebmeier (1983), dan lebih lanjut Confrey (1986), memperoleh temuan bahwa guru yang merencanakan dan mengimplementasikan lima langkah pembelajaran matematikanya, akan lebih sukses dibanding dengan mereka yang menggunakan pendekatan tradisional. Kelima langkah inilah yang biasa kita kenal sebagai Missouri Mathematics Project (MMP) yang terbukti lebih sukses (Setiawan: 2010). Pendapat lain menyatakan Sesuai dengan metode pembelajaran yang berpusat pada siswa (student centered) MMP cukup efektif dan efisien karena metode pembelajaran ini menggabungkan semua komponen yaitu keaktifan siswa, kecakapan guru, yang nantinya kedua hal tersebut akan sangat berpengaruh terhadap hasil belajar siswa (Vita Heprilia Dwi Kurniasari, Susanto dan Toto' Bara Setiawan: 2014). Sedangkan metode Numbered Head Together (NHT) menekankan pada aktifitas siswa dalam kelompok dengan melakukan diskusi, kerjasama, saling membantu, dan semua anggota kelompok mempunyai peran dan tanggung jawab yang sama. Numbered Head Together (NHT) merupakan salah satu dari stategi pembelajaran kooperatif.Metode pembelajaran ini dikembangkan oleh Spencer Kagan (1993). Metode Numbered Head Together (NHT) mengacu pada belajar kelompok siswa, masingmasing anggota memiliki bagian tugas (pertanyaan) dengan nomor yang berbeda-beda(Aris Soimin: 2014). Setiap siswa mendapatkan kesempatan sama untuk menunjang timnya guna memperoleh nilai maksimal sehingga termotivasi untuk belajar. Dengan demikian setiap individu merasa mendapat tugas dan tanggung jawab sehingga tujuan pembelajaran dapat tecapai. Tujuan dari Numbered Head Together (NHT) adalah memberi kesempatan kepada siswa untuk saling berbagi gagasan dan mempertimbangkan jawaban yang tepat Selain untuk meningkatkan kerja sama siswa, Numbered Head Together (NHT) juga bisa diterapkan untuk semua mata pelajaran dan tingkatan kelas (Miftahul Huda: 2015)

Kelebihan metode Missouri Mathematics Project (MMP) adalah menjembatani antara teacher centered learning ke arah student centered learning. Karena, kenyataan di lapangan sangat sulit rasanya mengubah kebiasaan guru yang "berkuasa" menjadi "fasilitator", yang "berbicara" menjadi "pengamat", karena materi yang tersampaikan kepada siswa tidak terlalu memakan banyak waktu dan semakin banyak latihan sehingga siswa mudah dan terampil dengan beragam soal. Sedangkan kelebihan dari metode Numbered Head Together (NHT) antara lain adalah setiap siswa menjadi siap semua, siswa dapat melakukan diskusi dengan sungguh-sungguh, siswa yang pandai dapat mengajari siswa yang kurang pandai.

Kesamaan antara metode Missouri Mathematics Project (MMP) dan Numbered Head Together (NHT) yaitu memiliki gaya belajar yang berbentuk kelompok dan berdiskusi, latihan dalam mengerjakan soal dalam bentuk kelompok atau individu. Dengan demikian, penggunaan metode pembelajaran Missouri Mathematics Project (MMP) dan Numbered Head Together (NHT) menuntut siswa untuk lebih aktif dalam proses pembelajarannya, diharapkan siswa terbiasa untuk menyelesaikan soal-soal atau memecahkan suatu masalah yang berbeda sehingga 
dalam menyelesaikan soal atau memecahkan masalah dapat tersusun dengan baik.

\section{METODE}

Sasaran Penelitian ini dilaksanakan pada siswa SMK Negeri 1 Gunung Putri yang beralamat di Jln. Barokah No.06 Desa Wanaherang, Kecamatan Gunung Putri Kabupaten Bogor. Semester Genap Tahun Ajaran 20172018 tepatnya mulai bulan oktober 2017 sampai bulai mei 2018, penelitian ini jenis penelitian eksperimen mengungkapkan hubungan antara dua variabel. Variabel penelitian adalah suatu atribut atau sifat atau nilai dari orang, obyek atau kegiatan yang mempunyai variasi tertentu yang ditetapkan oleh peneliti untuk dipelajari dan kemudian ditarik kesimpulannya. Variabel penelitian pada dasarnya adalah segala sesuatu yang berbentuk apa saja yang ditetapkan oleh peneliti untuk dipelajari sehingga diperoleh informasi tentang hal tersebut, kemudian ditarik kesimpulannya (Sugiyono: 2013). Variabel dalam penelitian ini ada 2 jenis yaitu variabel dependent (terikat) dan variabel independent (bebas). Dalam penelitian ini jenis eksperimen yang digunakan adalah eksperimen semu (quasi eksperimental). Pada penelitian ini variabel bebasnya adalah pembelajaran Metode MMP dan Metode NHT, sedangkan variabel terikatnya adalah hasil belajar matematika. Metode yang dipergunakan dalam penelitian ini adalah penelitian kuantitatif deskriptif dengan pendekatan eksperimen dan bentuk rancangannya berupa quasi eksperiment (eksperimen semu).Metode ini mempunyai kelompok kontrol, tetapi tidak dapat berfungsi sepenuhnya untuk mengontrol variabel-variabel luar yang mempengaruhi pelaksanaan eksperimen.

Penelitian ini dilakukan dengan mengamati perbedaan hasil belajar matematika antara pembelajaran Metode Missouri Mathematics Project (MMP) dan Metode Numbered Head Together (NHT), dimana peneliti turun langsung mengajar pada dua kelas yang berbeda.Pengumpulan data menggunakan tes tertulis dengan instrumen soal tes pilihan ganda, yaitu untuk mengukur hasil belajar matematika siswa pada materi trigonometri. Tes juga diberikan kepada siswa yang mengikuti pembelajaran konvensional untuk mengukur hasil belajar yang dicapai siswa dan terpilih sebagai sampel penelitian. Penelitian dapat diartikan sebagai suatu proses pengumpulan dan analisis data yang dilakukan secara sistematis dan logis untuk mencapai tujuan-tujuan tertentu (S.S Nana: 2011),

Populasi adalah wilayah generalisasi yang terdiri dari subjek yang mempunyai kualitas dan karakteristik tertentu yang ditetapkan oleh peneliti untuk dipelajari dan kemudian ditarik kesimpulannya (Sugiyono: 2015). Pada penelitian ini populasi targetnya adalah SMK N 1 Gunung
Putri Semester Genap, sedangkan populasi terjangkau adalah seluruh siswa kelas X SMKN 1 Gunung Putri pada semester genap. Pada penelitian ini sampelnya adalah kelas X Elektro 2 dengan jumlah 36 siswa sebagai kelas eksperimen I dan kelas X Elektro 1 dengan jumlah 36 siswa sebagai kelas eksperimen 2. Teknik pengambilan sampel menggunakan Cluster Random Samping. Instrumen penelitian adalah suatu alat yang digunakan untuk mengukur fenomena alam maupun sosial yang diamati.Instrumen penelitian yang digunakan untuk mengumpulkan data berupa tes. Tes merupakan alat atau prosedur yang digunakan untuk mengetahui atau mengukur sesuatu dalam suasana dengan cara dan aturan-aturan yang sudah ditetapkan (Suharsimi Arikunto: 2017) Instrumen yang digunakan dalam penelitian ini adalah tes obyektif pilihan ganda dengan lima alternatif jawaban. Yaitu a, b, c, d, e dengan Jumlah seluruh soal 35 butir soal. Untuk setiap responden yang menjawab benar satu butir soal diberi skor 1 (satu) dan yang menjawab salah diberi skor 0 (nol), dengan demikian skor terendah siswa adalah 0 dan skor tertinggi siswa adalah 30. Pengujian instrumen sangat diperlukan untuk mengetahui apakah tes tersebut sudah memenuhi persyaratan tes seperti validitas (tingkat kesahihan), reliabilitas (tingkat keajegan), Daya Pembeda dan Taraf Kesukaran dalam hal ini peneliti lakukan uji coba instrumen pada siswa kelas X Elektro 3.

Analisis data untuk mengetahui perbedaan hasil belajar matematika siswa menggunakan Metode Missouri Mathematics Project (MMP) dan Metode Numbered Head Together (NHT) diuji dengan menggunakan uji t, yaitu uji satu arah dengan varians yang sama besar. Sebelum melaksanakan uji t, dilakukan uji normalitas dan uji homogenitas karena sebagai syarat analisis data yang akan diuji harus berdistribusi normal dan mempunyai varians yang sama atau homogen.

\section{HASIL DAN PEMBAHASAN}

Pelaksanaan Uji coba soal insturmen tes hasil belajar matematika pada penelitian ini dilaksanakan di kelas XI Elektro SMKN 1 Gunung Putri, dengan jumlah responden 33 orang siswa. Materi dalam tes ini uji coba instrumen adalah trigonometri dengan jumlah soal 30 butir berbentuk pilihan ganda dengan 5 alternatif pilihan jawaban yaitu a, b, c,d dan e. Berdasarkan hasil perhitungan uji validitas menggunakan poin biserial diperoleh koefisien poin biserial untuk tiap butir soal, melebihi $r$ tabel yaitu untuk signifikasi $=0.5$ dan $\mathrm{N}=36$ adalah 0.329 , sehingga dari perhitungan tersebut diperoleh soal yang valid adalah 25 butir soal.

Dari data hasil penelitian yang dideskripsikan adalah data hasil belajar matematika yang diperoleh siswa setelah tes dilaksanakan pada kelas eksperimen I dan eksperimen 
II. Pada eksperimen I jumlah siswa sebanyak 36 dan eksperimen II jumlah siswa 36. Data penelitian yang dianalisis adalah rata-rata skor hasil belajarmatematika siswa pada kelas eksperimen 1 dan kelas eksperimen 2.Data ini diolah menjadi skor rata-rata, standar deviasi dan varians seperti pada tabel Tabel 1 .

Tabel 1. Hasil Tes Akhir dari Kelas Sampel

\begin{tabular}{|c|c|c|c|c|}
\hline Kelas & $\mathrm{N}$ & $\bar{X}$ & $\mathrm{~S}$ & $\mathrm{~S}^{2}$ \\
\hline Eksperimen 1 & 36 & 76,5 & 11,036 & 121,8 \\
\hline Eksperimen 2 & 36 & 71,33 & 10,04 & 100,8 \\
\hline
\end{tabular}

Berdasarkan hasil pada Tabel 1, terlihat bahwa rata-rata hasil belajar matematika pada kelas eksperimen 1 yang melakukan pembelajaran dengan mneggunakan metode pembelajaran kooperatif tipe Missouri Mathematics Project (MMP) lebih tinggi daripada kelas eksperimen 2 yang melakukan pembelajaran dengan menggunakan metode pembelajaran kooperatif tipe Numbered Head Together (NHT). Hasil perhitungan uji normalitas dan uji homogenitas antara kelompok eksperimen 1/dan kelompok eksperimen 2 dapat dilihat pada tabel 2 dan tabel 3.

Tabel 2. Hasil Uji Normalitas Data

\begin{tabular}{|c|c|c|c|c|c|}
\hline Kelas & $\mathrm{N}$ & $\mathrm{A}$ & $\mathrm{L}_{\text {hitung }}$ & $\mathrm{L}_{\text {tabel }}$ & Ket. \\
\hline Eksperimen 1 & 36 & 0,05 & 0,1208 & 0,1477 & Normal \\
\hline Eksperimen 2 & 36 & 0,05 & 0,0930 & 0,1477 & Normal \\
\hline
\end{tabular}

Tabel 3. di atas terlihat bahwa data pada kedua kelas memiliki $\mathrm{L}_{\text {hitung }}<\mathrm{L}_{\text {tabel }}$, berarti data berdistribusi normal. Setelah uji normalitas, selanjutnya dilakukan uji homogenitas data.Hasil uji homogenitas kedua sampel terdapat pada Tabel 3

Tabel 3. Hasil Uji Homogenitas Data

\begin{tabular}{|c|c|c|c|c|}
\hline Kelas & $\mathrm{A}$ & $\mathrm{F}_{\text {hitung }}$ & $\mathrm{F}_{\text {tabel }}$ & Ket. \\
\cline { 1 - 4 } Eksperimen 1 & \multirow{2}{*}{0,05} & 1,149 & 1,76 & Homogen \\
\cline { 1 - 2 } Eksperimen 2 & & & & \\
\hline
\end{tabular}

Tabel 3 menunjukkan bahwa kedua kelas sampel memiliki $\mathrm{F}_{\text {hitung }}<\mathrm{F}$ tabel yang berarti data yang diperoleh memiliki varians yang homogen.

Berdasarkan hasil perhitungan uji normalitas dan uji homogenitas menunjukkan data berdistribusi normal dan memiliki varian yang homogen, sehingga untuk pengujian hipotesis digunakan uji t. Hasil uji hipotesis dapat dilihat pada Tabel 4.

Tabel 4. Hasil Uji Hipotesis

\begin{tabular}{|c|c|c|c|}
\hline Kelas & $\mathrm{t}_{\text {hitung }}$ & $\mathrm{t}_{\text {tabel }}$ & Kesimpulan \\
& & $(\alpha=0,05)$ & \\
\hline Eksperimen 1 & \multirow{2}{*}{2,068} & 1,994 & Hipotesis diterima \\
\cline { 1 - 2 } Eksperimen 2 & & & \\
\hline
\end{tabular}

Berdasarkan hasil uji t didapatkan thitung $=2,068$ dan harga ttabel $=1,994$ dan $\mathrm{t}$ hitung $>\mathrm{t}$ tabel, maka hipotesis diterima. Dapat disimpulkan terdapat perbedaan hasil belajar matematika siswa pada materi trigonometri yang diajarkan menggunakan metode pembelajaran kooperatif tipe Missouri Mathematics Project (MMP) dan tipe Numbered Head Together (NHT) kelas X SMKN 1 Gunung Putri. Hasil tersebut didukung oleh beberapa peneliti antara lain (Novalia, R., Makmuri, M., \& Sudrajat, A: 2018) menyatakan When viewed rom these resutl, the model of learning type of Missouri Mathematics Project to improve student learning outcomes in learning mathematics. Peneliti lain juga mengemukakan dari hasil penelitiannya (Kurniasari, V. H. D., \& Susanto, S: 2015) It can be concluded that the application of Missouri Mathematics Project learning model is able to improve student learning outcomes.

\section{PENUTUP}

\section{Simpulan}

Berdasarkan dari hasil penelitian dan pembahasan dapat disimpulkan bahwa hasil belajar siswa yang menggunakan metode Missouri Mathematics Project (MMP) memiliki perbedaan hasil belajar dengan siswa yang menggunakan metode Numbered Head Together(NHT).

\section{Saran}

Berdasarkan hasil penelitian didapat beberapa hal yang harus diperhatikan dan menjadi pembelajaran untuk menjadi bahan masukan dalam upaya meningkatkan prestasi siswa maka penulis memberikan beberapa saran sebabagai berikut. 1.Kelengkapan alat peraga dan sumber belajar yang berada di sekolah diperlukan agar siswa dapat belajar dengan prasarana yang maksimal. 2 Berdasarkan hasil penelitian bahwa pembelajaran matematika dengan metode pembelajaran kooperatif tipe Missouri Mathematics Project (MMP) mampu meningkatkan hasil belajar matematika siswa, sehingga pembelajaran tersebut dapat menjadi salah satu variansi pembelajaran matematika yang dapat diterapkan di kelas. 3. Model pembelajran Missouri Mathematics Project (MMP) dan Numbered Head Together(NHT) jika diterapkan dengan baik dan benar sesuai dengan langkah-langkah yang ada, dapat meningkatkan kualitas proses belajar mengajar. 4. Perlu 
adanya sosialisasi tentang penerapan model pembelajaran kooperatif agar pembelajaran matematika di sekolah akan menjadi lebih menarik dan menyenangkan karena siswa menjadi lebih aktif, kreatif dan lebih menyukai pembelajaran matematka dalam belajar, sehingga tidak ada kata takut dan bosan untuk belajar matematika

\section{DAFTAR PUSTAKA}

Arikunto, Suharsimi. 2017. Dasar-DasarEvaluasi Pendidikan Edisi Kedua. Jakarta: Bumi Aksara.

Budiyono. 2016. Statistika Untuk Penelitian,. Surakarta : UNS Press.

Good, Thomas L., and Grows, Douglas,A. The Missouri Mathematics Effectiveness Project: An Experimental Study in Fourth-Grade Classroom. Journal of Education Psychology:7 (3): 355-362. 1979.

Huda, Miftahul. 2015. Model-Model Pengajaran dan Pembelajaran. Yogyakarta: Pustaka Pelajar.

Kurniasari, V. H. D., \& Susanto, S. 2015. Penerapan Model Pembelajaran Missouri Mathematics Project dalam Meningkatkan Aktivitas Siswa dan Hasil Belajar Siswa Sub Pokok Bahasan Menggambar Grafik Fungsi Aljabar Sederhana dan Fungsi Kuadrat pada Siswa Kelas X SMAN Balung Semester Ganjil Tahun Ajaran 2013/2014. Pancaran: 4 (2): 153-162.

Kusuma, A. P., \& Susanty, I. Eksperimentasi Model Pembelajaran NHT dan Snowball Throwing pada Materi Bangun Ruang Sisi Datar Kelas VIII SMP AlNur Cibinong. Jurnal Pendidikan Matematika dan IPA, 10(1),52-62.

Kusuma, A. P., \& Khoirunnisa, A. (2018). Penerapan Model Pembelajaran Kooperatif Tipe Make a Match dan Team Games Tournament terhadap Hasil Belajar. NUMERICAL: Jurnal Matematika dan Pendidikan Matematika, 1-14.

Mangentang, D. F., Kusuma, A. P., Arihati, D. B., \& Rahmawati, N. K. (2018, September). Penerapan Model Pembelajaran Brain Based Learning Dan Model Pembelajaran Accelerated Learning Cycle Terhadap Hasil Belajar Matematika Pada Materi Logaritma. In Seminar Nasional dan Diskusi Panel Multidisiplin Hasil Penelitian dan Pengabdian Kepada Masyarakat 2018 (Vol. 1, No. 1).

Novalia, R., Makmuri, M., \& Sudrajat, A. (2018) Application of Type Cooperatif Learning Models Missouri Mathematics Project (MMP) to increase Learning Resulth Math. American Journal of Education Research, 6 (8), 1085-1092.

Rahmawati, N. K., \& Budiyono, B. (2014). Eksperimentasi Model Pembelajaran TTW dan NHT pada Materi Bangun Ruang Sisi Datar Ditinjau dari
Kemampuan Komunikasi Matematis Siswa. Jurnal Pembelajaran Matematika . 2(10).

Rahmawati, N. K., \& Setiani, S. (2018). Eksperimentasi Model Pembelajaran Snowball Throwing dan NHT Ditinjau dari Gaya Belajar Siswa pada Materi Himpunan Kelas VII SMP Avicenna Cileungsi.. Jurnal Pendidikan Matematika dan IPA, 10(1), 41-51.

Shoimin, Aris. 2014. 68 Model Pembelajaran Inovatif dalam Kurikulum 2013.Yogyakarta: Ar-Ruzz Media.

Sugiyono. 2015. Metode Penelitian Pendidikan :Pendekatan Kuantitatif, Kualitatif, dan R\&D. Bandung: Alfabeta.

Sukmadinata, Nana Syaodih. 2005. Landasan Psikologis Proses Pendidikan.Bandung: Remaja Rosda karya. 